\title{
Bacteria in the milk of sheep with or without mastitis- mini Review
}

\author{
1,2 Andualem Tonamo - ${ }^{1}$ István Komlósi - ${ }^{2}$ Ferenc Peles \\ ${ }^{1}$ Department of Animal Husbandry, Faculty of Agricultural and Food Sciences and Environmental Management, University of Debrecen, \\ Böszörményi street 138, 4032 Debrecen, Hungary \\ ${ }^{2}$ Institute of Food Science, Faculty of Agricultural and Food Sciences and Environmental Management, University of Debrecen, \\ Böszörményi Street 138, 4032 Debrecen, Hungary \\ andualemtonamo@gmail.com
}

\section{SUMMARY}

From a nutritional point of view, sheep milk is more valuable than cow and goat milk and the interest for sheep milk is increasing in many countries. However, sheep milk is easily contaminated during milking, handling, and transport and it is an ideal medium for bacterial propagation. Consequently, sheep milk spoils quite quickly. The proper, clean handling of milk is not only of sanitarian interest, but it also serves the farmers' interests, because contaminated milk may not be distributed, and is unsuitable for producing good quality products. Following this technological trend, this review addresses the bacterial composition of sheep milk with and without mastitis. Even though sheep milk contains a lot of bacteria, this review article highlighted total plate count, Enterobacteriaceae, coliform, Staphylococcus aureus, Escherichia coli, Listeria monocytogenes, Campylobacter, Salmonella spp. and Streptococcus spp. Mastitis in sheep is a vital cause of mortality, reduction in milk production and early culling. The reported risk factors for mastitis in sheep were age, a case of mastitis, breed, husbandry systems, and location. The main priority should be implementation of programs to minimize human pathogenic bacteria and mastitis in raw ewe milk.

Keywords: Mastitis, microorganisms, sheep milk

\section{INTRODUCTION}

According to Tsakalidou and Odos (2012), ewe milk is seldom consumed but $1.4 \%$ of global milk production is ewe milk as it is regularly used all over Europe in the manufacturing of cheese. Milk production by sheep has grown over the years and is now in search of new consumer markets (Selvaggi et al., 2014). The study from Greece by Fotou et al. (2011) conveyed that lactic acid bacteria dominated the microbial composition of sheep milk, with bacteria that grows best in moderate temperature representing $10^{2}$ $10^{6} \mathrm{cfu} / \mathrm{ml}$, whereas bacteria that grow at low temperature correspond to $10^{2}-10^{4} \mathrm{cfu} / \mathrm{ml}$. Different studies evaluated the effect of storage of ewe milk at refrigerator confirmed increases in not only in bacteria proliferating at low temperature but also in bacteria which grows best at medium temperature. However, the bacteria that is capable of surviving high temperature did not increase. Bacteria that were discovered occasionally can include microorganisms of concern from a milk safety outlook, comprising Escherichia coli, Salmonella, Staphylococcus aureus, Bacillus, and Clostridium perfringens (Fotou et al., 2011).

Bacterial composition of ewe milk can be affected by not only the nutritional composition of milk but also the location where sheep farm is found (Yabrir et al., 2013). Many studies noted that ewe milk with a highfat content resulted in greater counts of lactic acid bacteria, coliforms, and molds. In more acidic milk and milk with a lower level of nutrients, there were higher and lower populations of streptococci and S. aureus (Yabrir et al., 2013). Nevertheless, sheep milk production is booming, it does not have as high a production yield as another animal's milk due to seasonal dependency (Albenzio et al., 2016).

According to the finding of Mennane et al. (2007), sheep milk and its derivatives constitute a conducive environment to the growth of microorganisms, especially disease-causing bacteria and fungi; this is why they have always been considered as one of the main causes of food poisoning. Sheep milk quality and shelf life can negatively be impacted by bacteria; for instance, bacteria that can grow at low temperature can reproduce during refrigeration and, via the production of extracellular lipases and proteases, resulting in putrefaction (Hantsis-Zacharov and Halpern, 2007). The report of Oliver et al. (2009) indicated that the microorganisms in sheep milk can have well-being linked indications in the consumption of raw ewe milk with disease-causing microorganisms which can lead to in some cases severe illness. Therefore, this review was aimed with the emphasis on sheep milk bacterial composition and prevalence of mastitis in sheep.

\section{BACTERIAL COMPOSITION OF SHEEP MILK}

\section{Hygienic indicators in sheep milk}

The hygienic standards for the production and distribution of ewe milk are less strict, although there is increasing demand by consumers. The Regulation (EC) $853 / 2004$ of the European Parliament and of the Council for raw milk hygiene has been implemented in European Union countries, which is basically focused in cow milk hygiene (EC, 2004). According to the Regulation (EC) 853/2004 of the European Parliament and of the Council (EC, 2004), for milk from animal species other than cows which will undergo pasteurization must not exceed total plate count (TPC) of $1.5 \times 10^{6} \mathrm{cfu} / \mathrm{ml}$ and which is intended for processing 
without heat treatment must not exceed TPC of $5 \times 10^{5}$ $\mathrm{cfu} / \mathrm{ml}$.

Sheep raw milk potentially contains a diverse bacterial population. The occurrence of bacteria in ewe milk could be from various sources, mainly the environment of the farm and from the body of the animal to the milk (Quigley et al., 2013). Bacteria enter milk from these sources and, once in milk, can play a number of roles, such as facilitating dairy fermentations, causing spoilage or causing disease. Bogdanovičova et al. (2016) from the Czech Republic reported that sheep milk bacteriological quality can be determined using different parameters, such as the number of Enterobacteriaceae and the total bacterial count (TBC).

The study from Vermont by D'Amico and Donnelly (2010) pointed out that there was no significant difference in the TBC results of raw milk from sheep, goat, and cows. The TBC results of sheep milk differ according to the month in which the animal is milked, the milking system, the frequency of milking and the size of the herd (Alexopoulos et al., 2011). According to Alexopoulos et al. (2011) study, the results showed as an average, TBC was $5.48 \mathrm{lg} \mathrm{cfu} / \mathrm{ml}$, somatic cell count (SCC) was $6.05 \mathrm{lg}$ cells $/ \mathrm{ml}$, coliforms: $4.49 \mathrm{lg}$ $\mathrm{cfu} / \mathrm{ml}$ and environmental Streptococcus counts was $4.95 \mathrm{lg} \mathrm{cfu} / \mathrm{ml}$. Similarly, the study in Switzerland revealed that the TBC from bulk-tank of ewe was 4.78 $\lg \mathrm{cfu} / \mathrm{ml}$; Enterobacteriaceae were detected in 45 (71.4\%) ewe's milk samples (Muehlherr et al., 2003).

Somatic cell count is also a good indicator of the quality of sheep milk. Somatic cell count is generally considered as an indicator of udder health. High number of SCC in ewe milk is an indication that we are dealing with unsanitary milk and weakened ewe health (Bytyqi et al., 2013). However, there is no accepted threshold that can permit to differentiate between healthy and infected udders in dairy ewes, Berthelot et al. (2006) reported the udder as healthy if individual SCC is lower than $0.5 \times 10^{6}$ cells $/ \mathrm{ml}$, and infected if at least two individual SCC were higher than 1 or $1.2 \times$ $10^{6}$ cells $/ \mathrm{ml}$, while at the flock level, if SCC exceeded $0.65 \times 10^{6}$ cells $/ \mathrm{ml}$, they indicated up to $15 \%$ occurrence of mastitis. An overview of recent studies regarding the bacteriological quality and SCC of raw milk of sheep is shown in Table 1.

Table 1

Bacteriological quality and somatic cell count of sheep milk in different countries

\begin{tabular}{|c|c|c|c|c|}
\hline $\begin{array}{l}\text { Sample } \\
\text { type }\end{array}$ & Country & $\begin{array}{l}\text { № of } \\
\text { sample }\end{array}$ & Findings & References \\
\hline REM & Egypt & 35 & $\begin{array}{l}\text { The mean of TBC was } 2.04 \times 10^{6} \mathrm{cfu} / \mathrm{ml} \text {, Enterobacteriaceae count } \\
(\mathrm{EBC}) \text { was } 1.67 \times 10^{5} \mathrm{cfu} / \mathrm{ml} \text { and coliforms was } 1.66 \times 10^{5} \mathrm{cfu} / \mathrm{ml} \text {. }\end{array}$ & $\begin{array}{l}\text { Ombarak and Elbagory, } \\
2017\end{array}$ \\
\hline REM & Morocco & 44 & $\begin{array}{l}\text { Total bacterial count ranged from } 4.5 \times 10^{3} \text { to } 9.4 \times 10^{7} \mathrm{cfu} / \mathrm{ml}, 1.2 \times \\
10^{5} \mathrm{cfu} / \mathrm{ml} \text { of total coliforms and } 2 \times 10^{4} \mathrm{cfu} / \mathrm{ml} \text { of fecal coliforms. }\end{array}$ & Bouazza et al., 2015 \\
\hline REM & Egypt & 50 & $\begin{array}{l}\text { The results revealed that the presence of coliforms, yeast, and mold } \\
\text { with mean values of } 8.8 \times 10^{3} \pm 5.3 \times 10^{3}, 3.8 \times 10^{3} \pm 0.9 \times 10^{3} \text { and } 1.6 \\
\times 10^{3} \pm 0.2 \times 10^{3} \mathrm{cfu} / \mathrm{ml} \text {, respectively. }\end{array}$ & El-Makarem, 2016 \\
\hline ВTM & Switzerland & 63 & $\begin{array}{l}\text { Ewe's milk samples were tested for standard plate count and it was } \\
4.79 \mathrm{lg} \mathrm{cfu} / \mathrm{ml} \text {. }\end{array}$ & Zweifel et al., 2005 \\
\hline REM & Algeria & 105 & $\begin{array}{l}\text { The result revealed that TBC was } 90.2 \times 10^{3} \mathrm{cfu} / \mathrm{ml} \text { and } \mathrm{EBC} \text { was } 10.8 \\
\times 10^{2} \mathrm{cfu} / \mathrm{ml} \text {. }\end{array}$ & Fatima et al., 2013 \\
\hline REM & Greece & 240 & $\begin{array}{l}\text { Total mesophilic flora ranged from } 6.4 \times 10^{2} \text { to } 6.4 \times 10^{6} \mathrm{cfu} / \mathrm{ml} \text { and } \\
\text { total number of psychrotrophic bacteria was from } 5 \times 10^{2} \text { to } 5.1 \times 10^{4} \\
\text { cfu } / \mathrm{ml} \text {. }\end{array}$ & Fotou et al., 2011 \\
\hline REM & Hungary & 24 & $\begin{array}{l}\text { The mean values of TPC were } 3.25,3.60 \text { and } 3.81 \mathrm{lg} \mathrm{cfu} / \mathrm{ml} \text { in milk } \\
\text { samples from Dorper, Merino, and Cigaja, respectively. EBC was less } \\
\text { than } 10 \mathrm{cfu} / \mathrm{ml} \text {. }\end{array}$ & Tonamo et al., 2018 \\
\hline REM & Slovakia & 1192 & $\begin{array}{l}\text { The negative effect of high SCC on milk yield was observed in all } \\
\text { farms and milk samples had SCC below } 0.6 \times 10^{6} \text { cells } / \mathrm{ml} \text {. }\end{array}$ & Tančin et al., 2017a \\
\hline REM & Slovakia & 2159 & $\begin{array}{l}82.03 \% \text { of the tested samples were below } 4.0 \times 10^{5} \text { cells } / \mathrm{ml} \text { and only } \\
8.89 \% \text { over } 1.0 \times 10^{6} \text { cells } / \mathrm{ml} \text { indicating a good status of udder health } \\
\text { in tested animals. }\end{array}$ & Tančin et al., 2017b \\
\hline
\end{tabular}

REM: raw ewe milk, BTM: bulk tank milk, TBC: total bacterial count, EBC: Enterobacteriaceae count, SCC: somatic cell count

\section{Pathogens in sheep milk}

This review confirmed that many literature indicated that most of the disease outbreaks were related to the consumption of raw milk, which contains pathogenic microorganisms. The finding of Oliver et al. (2009) from the United States within six years confirmed that 12 disease outbreaks from raw milk samples that were caused by Listeria monocytogenes (1 outbreak), Campylobacter spp. (5 outbreaks), Salmonella spp. (4 outbreaks), and verotoxigenic Escherichia coli (2 outbreaks). According to the report by the European Food Safety Authority (EFSA) in 2017 (EFSA-ECDC, 2018), out of 33 outbreaks, 18 (54.5\%) strong-evidence outbreaks were caused by Campylobacter spp. originated from raw milk. Raw milk is a significant source of human infection due to 
Campylobacter (EFSA-ECDC, 2018). Campylobacter spp. was also reported in raw bulk tank milk from sheep in Scotland and the frequency of occurrence was $2.2 \%$ (Verraes et al., 2014).

Staphylococcus aureus and Escherichia coli were the two most important bacteria in case of ewe bulk tank milk (de Garnica et al., 2011). S. aureus is one of the highly prevalent pathogens in unpasteurized ewe milk (Marogna et al., 2012). The report from Switzerland indicated that from 63 milk samples from bulk tank examined, $33.3 \%$ were $S$. aureus positive (Muehlherr et al., 2003). According to the report by Alexopoulos et al. (2011) all the examined bulk tank milk samples were $S$. aureus positive in Greece. D'Amico and Donnelly (2010) found that in case of the examined 15 bulk tank milk samples, $47 \%$ of the samples were $S$. aureus positive in US. In addition, the research of Bogdanovičova et al. (2016) revealed that in case of the examined 23 bulk tank milk samples, $39.1 \%$ of the samples were $S$. aureus positive in Czech Republic. The research conducted by Normanno et al. (2007) in Italy indicated that $S$. aureus is a common pathogen that causes slight skin infection to more severe diseases such as pneumonia and septicemia.

Shiga toxin-producing Escherichia coli (STEC) is one of the emerging pathogen related to the consumption of raw milk (Meng et al., 2013). The study by Solomakos et al. (2009) pointed out that gastrointestinal diseases, food poisoning, and even death in some cases make this microorganism an insidious risk to human health. The European Union summary report on trends and sources of zoonosis, zoonotic agents and food-borne outbreaks showed as the most commonly reported STEC serotype in 2017 was $\mathrm{O} 157$ (31.93\%) followed by O26, O103 and O91 serotypes. Serotype group O157 was the most frequently reported cause of haemolytic-uraemic syndrome cases in 2017 (EFSA-ECDC, 2018). From Table 2 below, E. coli $\mathrm{O} 157$ was detected in Greece, $0.84 \%$ (Solomakos et al., 2009), Czech Republic 4.4\% (Bogdanovičova et al., 2016) and Spain 10.1\% (Rey et al., 2006). Another study from Switzerland and United States reported also 12.1\% (Muehlherr et al., 2003) and 0.75\% (D'Amico and Donnelly, 2008), respectively.

This review noted that most of the studies from bulk milk tank samples in Europe indicated that the frequencies of occurrence of L. monocytogenes ranged from 4.9 to $6.1 \%$ (Ruusunen et al., 2013). The study from farm tank milk in Czech Republic revealed that $4.4 \%$ prevalence of L. monocytogenes (Bogdanovičova et al., 2016). On the other hand, a recent report from Estonia confirmed that $29 \%$ prevalence of $L$. monocytogenes in the bulk tank milk samples (Kalmus et al., 2015). The review of Verraes et al. (2014) confirmed that the frequency of $L$. monocytogenes in raw sheep milk is below $4 \%$.

Salmonella spp. have been detected in raw milk from sheep and the frequency of occurrence was low and was 5\% (Fotou et al., 2011). However, different pieces of literature indicated the total absence of Salmonella spp. in raw milk of sheep. Streptococcus spp. have been detected in raw milk from sheep (Table 2). The study by Alexopoulos et al. (2011) revealed the mean value of Streptococcus spp. was $4.95 \mathrm{lg} \mathrm{cfu} / \mathrm{ml}$. However, the studies did not always mention whether the strains involved were able to produce toxins. An overview of recent studies regarding frequency of occurrence of Salmonella spp. and Streptococcus spp. in raw milk of sheep is presented in Table 2.

Frequency of occurrence of pathogenic microorganisms in raw milk of sheep

\begin{tabular}{|c|c|c|c|c|c|}
\hline Microorganisms & Type of sample & Country & $\begin{array}{l}\text { № of } \\
\text { sample }\end{array}$ & $\begin{array}{c}\text { Frequency of } \\
\text { occurrence }(\%)\end{array}$ & References \\
\hline Salmonella spp. & Bulk tank milk & Greece & 240 & 5 & Fotou et al., 2011 \\
\hline \multirow{3}{*}{ Human pathogenic $E$. coli } & Bulk tank milk & Greece & 595 & 0.84 & Solomakos et al., 2009 \\
\hline & Bulk tank milk & $\begin{array}{c}\text { Czech } \\
\text { Republic }\end{array}$ & 23 & 4.4 & Bogdanovičova et al., 2016 \\
\hline & $\begin{array}{l}\text { Bulk tank milk and fresh } \\
\text { cheese curds }\end{array}$ & Spain & 287 & 10.1 & Rey et al., 2006 \\
\hline Listeria monocytogenes & Bulk tank milk & $\begin{array}{c}\text { Czech } \\
\text { Republic }\end{array}$ & 23 & 4.4 & Bogdanovičova et al., 2016 \\
\hline \multirow{4}{*}{ Staphylococcus aureus } & Bulk tank milk & Switzerland & 63 & 33.3 & Muehlherr et al., 2003 \\
\hline & Farm tank milk & $\begin{array}{c}\text { Czech } \\
\text { Republic }\end{array}$ & 23 & 39.1 & Bogdanovičova et al., 2016 \\
\hline & Balk tank milk & US & 15 & 47 & $\begin{array}{l}\text { D'Amico and Donnelly, } \\
2010\end{array}$ \\
\hline & Bulk tank milk & Greece & 71 & 100 & Alexopoulos et al., 2011 \\
\hline Streptococcus spp. & Bulk tank milk & Greece & 65 & 100 & Alexopoulos et al., 2011 \\
\hline Mycobacterium avium & Bulk tank milk & Switzerland & 63 & 23.8 & Muehlherr et al., 2003 \\
\hline
\end{tabular}




\section{Mastitis in sheep and its risk factors}

Khan and Khan (2006) defined mastitis as swelling of the mammary gland usually caused by bacterial infection. According to Marogna et al. (2012), mastitis in sheep reduces the economic value of sheep for milk production due to reduced lifespan of ewes. The review of Bergonier et al. (2003) indicated that most of the reports on subclinical mastitis are from dairy sheep, where the prevalence ranges from 10 to $50 \%$. As indicated in Table 3 below, the prevalence of mastitis was highest in Netherland with 94\% (Koop et al., 2010) followed by $85 \%$ in Norway (Mørk et al., 2007). Only $2.5 \%$ prevalence was recorded in UK as reported by Claire et al. (2016). This review underlined that mastitis in dairy ewe results in a reduction in milk yield, ewe and lamb death, culling of chronically diseased ewes (Conington et al., 2008), and decreased live- weight gain in lambs (Huntley et al., 2012).

This review confirmed that from several pathogenic microorganisms, S. aureus is the most common clinical mastitis causing bacteria in sheep (Mavrogianni et al., 2011) and the report by Mørk et al., (2007) indicated that coagulase-negative staphylococci (CNS) was the most common cause of subclinical mastitis in dairy sheep. The review report by Bergonier et al. (2003) showed that the frequency of occurrence of clinical and sub-clinical mastitis in dairy ewes that is caused by $S$. aureus ranges from 20 to $60 \%$. However, this review confirmed that it ranges from 2.5 to $94 \%$ (Mørk et al., 2007; Arsenault et al., 2008; Koop et al., 2010; Marogna et al., 2010; Ozenc et al., 2011; Spanu et al., 2011; Blagitz et al., 2014; Claire et al., 2016).

The study by Marogna et al. (2010) in Italian and German flocks revealed that the prevalence of mastitis caused by Staphylococcus spp. ranges from 20 to 30\% and unsuitable housing conditions and unhygienic milking practices were reported risk factor. In addition to $S$. aureus and CNS, other bacteria that were related with the occurrence of mastitis in dairy ewe includes Bacillus cereus, Clostridium spp. (Fotou et al., 2011), Corynebacterium spp. (Spanu et al., 2011), Enterococcus spp. (Marogna et al., 2010), Listeria monocytogenes (Brugère-Picoux, 2008), Mycobacterium spp. (Nebbia et al., 2006). An overview of the frequency of occurrence of mastitis in dairy ewe is presented in Table 3 below.

Prevalence of mastitis in dairy sheep in different countries

\begin{tabular}{cccc}
\hline Country & Sample number & Prevalence $(\%)$ & References \\
\hline UK & 90 & 2.5 & Claire et al., 2016 \\
USA & 426 & 10 & Spanu et al., 2011 \\
Turkey & 464 & 11 & Ozenc et al., 2011 \\
Canada & 696 & 18 & Arsenault et al., 2008 \\
Brazil & 550 & 24 & Blagitz et al., 2014 \\
Italy & 2198 & 50 & Marogna et al., 2010 \\
Norway & 547 & 85 & Mørk et al., 2007 \\
Netherland & 31 & 94 & Koop et al., 2010 \\
\hline
\end{tabular}

Various factors associated with management of ewes have been reported as possible risk factors for mastitis. Of these, some can be related to specific causative bacterial agents. Our review, inveterate that as indicated by many studies, the litter size, age, case of mastitis, ewe breed, husbandry systems and location are considered to be risk factors for mastitis in dairy sheep (Onnasch et al., 2002; Huntley et al., 2012; Cooper et al., 2013 and Pereira et al., 2014). Increased incidence risk of clinical and subclinical mastitis in ewes with vitamin A and selenium deficiencies has been reported (Koutsoumpas et al., 2013). Recently, reduced feed-energy availability has been recognized as a risk factor for mastitis in ewes (Barbagianni et al., 2015). A genetic background to increased susceptibility in mastitis in dairy ewes has also been reported (Bramis et al., 2014). These authors have suggested that, in a selection of ewes for resistance to mastitis, the use of reduced log-transformed somatic cell score may be employed as an indirect trait.

\section{CONCLUSION}

In conclusion, consumption of raw sheep milk poses problems to health due to human pathogenic bacteria in raw milk. In this review, bacteria in sheep milk with and without mastitis were collated based on the frequencies of occurrence of pathogenic microorganisms and disease outbreaks connected to consumption of raw ewe milk. Staphylococcus aureus, Escherichia coli and Listeria monocytogenes are highly prevalent pathogenic bacteria in raw sheep milk. Staphylococcus aureus and coagulase-negative staphylococci were the most common clinical and subclinical mastitis causing bacteria in dairy sheep, respectively. Mastitis in ewe results in the financial problem, loss of ewe and lambs, reduction of milk yield and loss of live-weight. Therefore, the main priority should be implementation of programs to minimize human pathogenic bacteria and mastitis in raw ewe milk. 


\section{ACKNOWLEDGEMENT}

The publication is supported by the EFOP-3.6.3VEKOP-16-2017-00008 project. The project is co- financed by the European Union and the European Social Fund.

\section{REFERENCES}

Albenzio, M.-Santillo, A.-Avondo, M.-Nudda, A.-Chessa, S.Pirisi, A.-Banni, S. (2016): Nutritional properties of small ruminant food products and their role on human health. Small Ruminant Research, 135. 3-12.

Alexopoulos, A.-Tzatzimakis, G.-Bezirtzoglou, E.-Plessas, S.Stavropoulou, E.-Sinapsis, E. (2011): Microbiological quality and related factors of sheep milk produced in farms of $\mathrm{NE}$ Greece. Anaerobe, 17. 276-279.

Arsenault, J.-Dubreuil, P.-Higgins, R.-Belanger, D. (2008): Risk factors and impacts of clinical and subclinical mastitis in commercial meat-producing sheep flocks in Quebec Canada. Preventive Veterinary Medicine, 87. 373-393.

Barbagianni, M. S.-Mavrogianni, V. S.-Katsafadou, A. I.-Spanos, S. A.-Tsioli, V.-Galatos, A. D.-Nakou, M.-Valasi, I.-Gouletsou, P. G.-Fthenakis, G. C. (2015): Pregnancy toxaemia as predisposing factor for development of mastitis in sheep during the immediately post-partum period. Small Ruminant Research. 130. 246-251

Bergonier, D.-De Crémoux, R.-Rupp, R.-Lagriffoul, G.-Berthelot, X. (2003): Mastitis of dairy small ruminants. Veterinary Research, 34. 689-716.

Berthelot, X.-Lagriffoul, G.-Concordet, D.-Barillet, F.-Bergonier, D. (2006): Physiological and pathological thresholds of somatic cell counts in ewe milk. Small Ruminant Research, 62. 27-31.

Blagitz, M. G.-Souza, F. N.-Batista, C. F.-Diniz, S. A.-Haddad, J. P.-Benites, N. R.-Melville, P. A.-Della Libera, A. M. (2014): Clinical findings related to intramammary infections in meatproducing ewes. Tropical Animal Health and Production 46 127-132.

Bogdanovičova, K.-Vyletělova-Klimešova, M.-Babak, V.Kalhotka, L.-Kolačkova, I.-Karpiškova, R. (2016): Microbiological quality of raw milk in the Czech Republic. Czech Journal of Food Science, 34. 189-196.

Bouazza, F. B.-Hassikou, R.-Ennadir, J.-Mouncif, M.-Mennane, Z.-Khedid, K. (2015): Microbiological and Physico-chemical Proprieties of Raw Sheep Milk from Sardi Breed. Global Advanced Research Journal of Agricultural Science. 302-308.

Bramis, G.-Arsenos, G.-Psifidi, A.-Banos, G. (2014): Genetic parameters of mastitis related traits in dairy sheep. Proceedings of the Annual Conference of the British Society of Animal Science (Nottingham, UK) p 194

Brugère-Picoux, J. (2008): Ovine listeriosis. Small Ruminant Research, 76. 12-20.

Bytyqi1, H.-Mehmeti, H.-Vehapi, I.-Rrustemaj, F.-Mehmeti, I. (2013): Effect of Bacterial Content and Somatic Cell Count on Sheep Milk Quality in Kosovo. Food and Nutrition Sciences, 4. 414-419.

Claire, G.-Mark, S.-Elizabeth G. (2016): A longitudinal study of factors associated with acute and chronic mastitis and their impact on lamb growth rate in 10 suckler sheep flocks in Great Britain. Preventive Veterinary Medicine, 127. 27-36.

Conington, J.-Cao, G.-Stott, A.-Bünger, L. (2008): Breeding for resistance to mastitisin United Kingdom sheep, a review and economic appraisal. Veterinary Record, 162. 369-376.
Cooper, S.- Huntley, S. J.-Green, L. E. (2013): A longitudinal study of risk factors for teat lesions in 67 suckler ewes in a single flock in England. Preventive Veterinary Medicine, 110. 232-241.

de Garnica, M. L.-Santos, J. A.-Gonzalo, C. (2011): Influence of storage and preservation on microbiological quality of silo ovine milk. Journal of Dairy Science, 94. 1922-1927.

D'Amico, D. J.-Donnelly, C. W. (2008): Low incidence of foodborne pathogens of concern in raw milk utilized for farmstead cheese production. Journal of Food Protection, 71. 1580-1589.

D'Amico, D. J.-Donnelly, C. W. (2010): Microbiological quality of raw milk used for small-scale artisan cheese production in Vermont: effect of farm characteristics and practices. Journal of Dairy Science, 93. 134-147.

EFSA-ECDC. (2018): Scientific report of EFSA and ECDC: The European Union summary report on trends and sources of zoonoses, zoonotic agents and food-borne outbreaks in 2017. European Food Safety Authority Journal, 10. 2903.

El-Makarem, A. H. S. (2016): Chemical and microbiological quality of ewe's milk. $3^{\text {rd }}$ International Food Safety Conference, Damanhur University.

European Commission (EC) (2004): Regulation (EC) No.853/2004 of the European Parliament and of the Council of 29. April 2004, laying down specific hygiene roles for foodstuffs. Official Journal of the European Communities.

Fotou, K.-Tzora, A.-Voidarou, C. H.-Alexopoulos, A.-Plessas, E.Avgeris, I.-Bezirtzoglou, E.-Akrida-Demertzi, K.-Demertzis, P. G. (2011): Isolation of microbial pathogens of subclinical mastitis from raw sheep's milk of Epirus (Greece) and their role in its hygiene. Anaerobe, 315-319.

Hantsis-Zacharov, E.-Halpern, M. (2007): Chryseobacterium haifense sp. nov., a psychrotolerant bacterium isolated from raw milk. International journal of systematic and evolutionary microbiology, 57. 2344-2348.

Huntley, S. J.-Cooper, S.-Bradley, A. J.-Green, L. E. (2012): A cohort study of the associations between udder conformation, milk somatic cell count, and lamb weight in suckler ewes. Journal of Dairy Science, 95. 5001-5010.

Kalmus, P.-Kramarenko, T.-Roasto, M.-Meremäe, K.-Viltrop, A. (2015): Quality of raw milk intended for direct consumption in Estonia. Food Control, 51. 135-139.

Khan, M. Z.-Khan, A. (2006): Basic facts of mastitis in dairy animals. Pakistan Veterinary Journal, 26. 204-208.

Koop, G.-Rietman, J. F.-Pieterse, C. (2010): Staphylococcus aureus mastitis in Texel sheep associated with suckling twins. Veterinary Record, 167. 868-869.

Koutsoumpas, A. T.-Giadinis, N. D.-Petridou, E. J.-Konstantinou, E.-Brozos, C.-Lafi, S. Q.-Fthenakis, G. C.-Karatzias, H. (2013): Consequences of reduced vitamin A administration on mammary health of dairy ewes. Small Ruminant Research. 110. 120-123.

Marogna, G.-Rolesu, S.-Lollai, S.-Tola, S.-Leori, G. (2010): Clinical findings in sheep farms affected by recurrent bacterial mastitis. Small Ruminant Research, 88. 119-125 
Marogna, G.-Pilo, C.-Vidili, A.-Tola, S.-Schianchi, G.-Leori, S. G. (2012): Comparison of clinical findings, microbiological results, and farming parameters in goat herds affected by recurrent infectious mastitis. Small Ruminant Research, 102. 74-83.

Mavrogianni, V. S.-Menzies, P. I.-Fragkou, I. A.-Fthenakis, G. C. (2011): Principles of mastitis treatment in sheep and goats. The Veterinary clinics of North America. Food animal practice, 27. 115-120.

Meng, J.-LeJeune, J. T.-Zhao, T.-Doyle, M. P. (2013): Enterohemorrhagic Escherichia coli. Food Microbiology, 287309.

Mennane, Z.-Ouhssine, M.-Khedid, K.-Yachioui, M. (2007): Hygienic quality of raw cow's milk feeding from domestic waste in tow regions in Morocco. International Journal of Agriculture and biology, 46-48.

Mork, T.-Waage, S.--Tollersrud, S.-Kvitle, B.-Sviland, S. (2007): Clinical mastitis in ewes; bacteriology, epidemiology and clinical features. Acta Veterinaria Scandinavica, 49. 23-30.

Muehlherr, J. E.-Zweifel, C.-Corti, S.-Blanco, J. E.-Stephan, R. (2003): Microbiological quality of raw goat's and ewe's bulktank milk in Switzerland. Journal of Dairy Science, 86. 38493856.

Nebbia, P.-Robino, P.-Zoppi, S.-De Meneghi, D. (2006): Detection and excretion pattern of Mycobacterium avium subspecies paratuberculosis in milk of asymptomatic sheep and goats by Nested-PCR. Small Ruminant Research, 66. 116-120.

Normanno, G.-Corrente, M.-La Salandra, G.-Dambrosio, A.Quaglia, N. C.-Parisi, A.-Greco, G.-Bellacicco, A. L.-Virgilio, S.-Celano, G. V. (2007): Methicillin-resistant Staphylococcus aureus (MRSA) in foods of animal origin product in Italy. International Journal of Food Microbiology, 117. 219-222.

Oliver, S. P.-Boor K. J.-Murphy, S. C.-Murinda, S. E. (2009): Food safety hazards associated with consumption of raw milk. Foodborne Pathogens and Disease, 6. 793-806.

Ombarak, R. A.-Elbagory, A. M. (2017): Bacteriological quality and occurrence of some microbial pathogens in goat's and ewe's milk in Egypt. International Food Research Journal. 24. 847-851.

Onnasch, H.-Healy, A.-Brophy, P.-Kinsella, A.-Doherty, M. (2002): A study of mastitis in Irish sheep. Research of Veterinary Science, 72. 42.

Ozenc, E.-Seker, E.-Baki Acar, D.-Birdane, M. K.-Darbaz, I.Dogan, N. (2011): The importance of staphylococci and threshold value of somatic cell count for diagnosis of sub-clinical mastitis in Pirlak sheep at mid-lactation. Reproduction in Domestic Animals, 46. 970-974.

Pereira, P. F. V.-Stotzer, E. S.-Pretto-Giordano, L. G.-Mueller, E. E.-Lisboa, J. A. (2014): Risk factors, etiology and clinical factors of mastitis in meat ewes of Parana, Brazil. Brazilian Journal of Veterinary Science, 34. 1-10.

Quigley, L.-O'Sullivan, O.-Beresford, T. P.-Ross, R. P.-Fitzgerald, G. F.-Cotter, P. D. (2013): The complex microbiota of raw milk. FEMS Microbiology Reviews, 37. 664-698.
Rey, J.-Sanchez, S.-Blanco, J. E.-Hermoso de Mendoza, J.Hermoso de Mendoza, M.-García, A. (2006): Prevalence, serotypes and virulence genes of Shiga toxin-producing Escherichia coli isolated from ovine and caprine milk and other dairy products in Spain. International Journal of Food Microbiology, 107. 212-217.

Ruusunen, M.-Salonen, M.-Pulkkinen, H.-Huuskonen, M.Hellström, S.-Revez, J.-Lindström, M. (2013): Pathogenic bacteria in Finnish bulk tank milk. Foodborne Pathogens and Diseases, 10. 99-106.

Selvaggi, M.-Laudadio, V.-Dario, C.-Tufarelli, V. (2014): Investigating the genetic polymorphism of sheep milk proteins: a useful tool for dairy production. Journal of the Science of Food and Agriculture, 94:3090-9.

Solomakos, N.-Govaris, A.-Angelidis, A. S. (2009): Occurrence, virulence genes and antibiotic resistance of Escherichia coli O157 isolated from raw bovine, caprine and ovine milk in Greece. Food Microbiology, 26. 865-871.

Spanu, C.-Berger, Y. M.-Thomas, D. L.-Ruegg, P. L. (2011): Impact of intramammary antimicrobial dry treatment and teat sanitation on somatic cell count and intramammary infection in dairy ewes. Small Ruminant Research, 97. 139-145.

Tančin, V.-Uhrinčat', M.-Mačuhová, L.-Baranovič, Š.-Vršková M. (2017a): Somatic cell count in milk of individual lacaune ewes under practical conditions in slovakia: possible effect on milk yield and its composition. Potravinarstvo Slovak Journal of Food Sciences.11. 386-390.

Tančin, V.-Baranovič, S.-Uhrinčat', M.-Mačuhová, L.-Vršková M.-Oravcová, M. (2017b): Somatic cell counts in raw ewes' milk in dairy practice: frequency of distribution and possible effect on milk yield and composition. Journal for dairy production and processing improvement.67. 253-260.

Tonamo A.-Komlósi, I.-Petróczki M. F.-Orosz, E.-Aamir, M.Peles, F. (2018): Microbiological quality of raw milk and udder surface samples from Dorper, Merino and Cigaja sheep breeds. Scientific researches in food production- $3^{\text {rd }}$ meeting of young researchers from V4 countries. University of Debrecen. 55-58.

Tsakalidou, E.-Odos, I. (2012): Microbiota of Goat's Milk and Goat's Milk Cheese. Proceedings of First Asia Dairy Goat Conference, pp. 40-41.

Verraes, C.-Claeys, W.-Cardoen, S.-Daube, G.-De Zutter, L.Imberechts, H.-Dierick, K.-Herman, L. (2014): A review of the microbiological hazards of raw milk from animal species other than cows. International Dairy Journal 39, 121-130.

Yabrir, B.-Hakem, A.-Laoun, A.-Labiad, M.-Nazek, E. G.Hamadi, A.-Abderrahmane M. (2013): Does the aridity of Algerian Steppe affect the Ewe's raw milk quality? Bulletin of the University of Agricultural Sciences and Veterinary, 69: 1-9.

Zweifel, C.-Muehlherr, J. E.-Ring, M.-Stephan, R. (2005): Influence of different factors in milk production on standard plate count of raw small ruminant's bulk-tank milk in Switzerland. Small Ruminant Research. 58. 63-70. 